\title{
Sofokles: življenje in delo, zbrano v samo sedmih dramah
}

\section{Aleksandar Gatalica}

Beograd, Srbija

https://orcid.org/0000-0003-1717-4691

aleksandar.gatalica@gmail.com

Sofokles je bil antični Shakespeare. Ni le vez med starim in novim grškim gledališcem, ampak je z jasnostjo svojega sloga, natančnostjo pesnjenja in popolnoma izčiščeno tragedijo dolga stoletja predstavljal zgled pisatelja za stare Grke in njihove dediče. Kljub temu se je ohranilo skoraj trikrat manj Sofoklovih tragedij kot Evripidovih. Zakaj? Tekstološka analiza pokaže eno od potencialnih razlag: ker je bil Sofokles kanoniziran, so njegove drame v rokopisih hranili le na majhnem številu posebnih mest. Danes je ohranjenih sedem Sofoklovih del in obsežni fragmenti ene satirske igre, ki so mu pripisani z zelo veliko mero gotovosti. Antigona sodi med tiste drame, ki so stoletja veljale za hrbtenico razumevanja Sofokla. Manj znano je dejstvo, da v Sofoklejevi zadnji pisani drami, Ojdipu v Kolonu, srečamo nekakšno proto-Antigono.

Ključne besede: grška tragedija / grško gledališče / Sofokles / Antigona / Ojdip v Kolonu

Za Sofokla bi lahko brez velikega pretiravanja rekli, da je bil antični Shakespeare. Za to obstajata dva bistvena razloga: prvi, ki ga slišimo najpogosteje, in drugi, ki mu umetnikove biografije skoraj nikoli ne pripisujejo pomembnosti. Prvi razlog, da je Sofokles postal edinstvena, neprimerljiva antična dramska veličina, je tisto, kar je tudi Shakespeara umestilo med elizabetinske klasike. Sofokles - prav tako kot njegov novoveški pendant - staro gledališče povezuje z novim. Medtem ko lahko o Shakespearu brez bojazni rečemo, da je bil veliki most med zabavljaškimi britanskimi ljudskimi odri srednjega veka in refleksivnim, miselnim novoveškim gledališčem, bi o Sofoklu lahko trdili, da je v svojem delu povezal dve obdobji antične tragiške igre. Ko je stopil na antični dionizični oder, je v tragediji še prevladovala drama, podobna nekemu velikemu oratoriju z religiozno tematiko, kakor pri njegovem velikem predhodniku Ajshilu. Ko pa je končal dramo Ojdip v Kolonu in leta 406 pr. Kr. zapustil teatrsko in življenjsko prizorišče, so se dionizična tekmovanja tragedov že davno preobrazila v sofistične spopade in vsakdanja modrovanja. 
Da bi na ta način povezal dve obdobji, mora biti umetnik obdarjen z ustvarjalnim zanosom, odprt za nova gibanja in celo za modo prihodnjih časov, predvsem pa mora imeti srečo, ki ji v opisih ustvarjanja velikih umetnikov pogosto ne naklanjamo pozornosti. Ponavadi rečemo, da umetnik potrebuje iskro talenta, ki se lahko pokaže $\mathrm{v}$ samo nekaj letih ustvarjanja ali celo v enem samem delu, pri čemer trajnost procesa ni posebnega pomena. Sofokles pa potrdi nasprotno. Ta avtor je namreč - za antične razmere - živel zelo dolgo. Rodil se je leta 496 pr. Kr. in umrl kot devetdesetletnik. Do smrti je bil, kot že rečeno, zelo plodovit pisatelj. V svojem devetdesetletnem življenju je Sofokles eno celo desetletje - med leti 468 pr. Kr. in 458 pr. Kr. - tekmoval proti Ajshilu ter od leta 455 pr. Kr. skoraj pol stoletja proti Evripidu. Tega je na koncu za nekaj mesecev celo preživel in je na tekmovanju leta 406 pr. Kr. svoj zbor odel v črnino, in sicer v čast vrnitvi telesa Evripida, ki naj bi po enem od izročil umrl v makedonski Aretusi, v Atene.

Kar je Sofoklu uspelo narediti v več kot šestih desetletjih umetniškega ustvarjanja, lahko le stežka predstavimo z današnjimi merili življenja in trajanja umetniške kariere. $V$ antiki je bil že petdesetletnik precej star, življenje po dopolnjenih osemdesetih letih pa je zabeleženo le nekajkrat. Zato se je tedaj vse dogajalo sorazmerno hitreje kot v poznejših časih. Zlato obdobje 5. stoletja pr. Kr., stoletja antičnega gledališča, lahko primerjamo z dvema stoletjema razvoja novega teatra. Da bi lahko dosegel tisto, kar se je posrečilo Sofoklu, bi sodobni gledališki umetnik po današnjih kriterijih moral živeti skoraj sto petdeset let. Svoj opus bi moral začeti kot mlad pristaš Schillerja, v zreli dobi nadaljevati kot privrženec Ibsenovega gledališča situacije ter naposled kariero končati v rivalstvu $\mathrm{z}$ Ionescom in Beckettom pri pisanju dram, ki sodijo h gledališču absurda.

\section{Življenjepis}

Sofokles se je rodil v Kolonu, predmestju Aten, deset stadijev (ali kakšna dva in pol kilometra) severno od prestolnice. Zato se ni imel za prišleka (kot Evripid, domnevno rojen v Salamini), temveč za pristnega Atenca. Temu v prid govori tudi dejstvo, da je bil Kolon, katerega lepoto opeva Sofoklov Ojdip v Kolonu, svojevrstno sveto mesto, kjer je bilo po okoliških hribih in poljanah veliko templjev in spomenikov bogovom.

S takšnim - lahko bi rekli pedigriranim - atenskim poreklom, je imel Sofokles od samega začetka pomemben položaj med svobodnimi 
atenskimi meščani. Bil je ugleden in svojega znanja ni hotel zadržati zase; zato se je, kot bi danes temu rekli, pridno posvečal tudi pedagoškemu delu. Med njegovimi učenci - in mladimi ljubimci - omenjajo dramatika Iona s Hiosa in heroja Halona.

Veliki pesnik ni bil slaven samo kot umetnik. Nekajkrat je vstopil tudi v politiko in javno življenje. Leta 443 pr. Kr. ga omenjajo kot blagajnika Aten, leta 441 pr. Kr. pa se pojavlja kot eden izmed Periklejevih vojaških svetovalcev (strategoi ). Leta 413 pr. Kr. je naposled postal del posebne skupine svetovalcev, t. i. probuli.

Vseeno se je najbolj posvečal odrski umetnosti. Ustvarjal je skozi celo 5. stoletje in dosegel vse, kar je bilo v umetnosti njegove dobe moč doseči. Ko je po tolikih podvigih in dominantni prisotnosti na odru umrl, je postal atenski heroj; čeprav so si številni avtorji, kot ponavadi, šele takrat oddahnili. Aristofan je v komediji Žabe zapisal, da se je Sofokles končno "poslovil« in nato dodal: to je naredil »z lahkoto«. ${ }^{1}$

\section{Dramatikova kariera}

Sofokles je najbolj znan in najbolj nagrajevan antični dramski pisec. $\mathrm{Na}$ dramski oder je stopil leta 468 pr. Kr. in že na svojem začetniškem tekmovanju prejel prvo nagrado ter premagal Ajshila. Napisal je več kot $120 \mathrm{del}^{2}$ in prejel vsaj dvajset dokumentiranih nagrad na dionizijah. Med nagradami je bilo največ prvih, le nekajkrat je bil drugi, nikoli tretji (oziroma zadnji na tekmovanju). Kljub dejstvu, da je bil tako popularen, imamo danes le sedem njegov dram, ki so ohranjene v celoti ali pa neznatno "poškodovane", in sicer po najverjetnejšem kronološkem redu: Ajant, Antigona, Trahinke, Kralj Ojdip, Elektra, Filoktet in Ojdip $v$ Kolonu. Po nenadni najdbi je bila $\mathrm{k}$ temu seznamu leta 1911 dodana tudi skoraj neokrnjena satirska drama Sledilni psi, čeprav zgodba o atribuciji tega dela še ni popolnoma zaključena. ${ }^{3}$

Danes lahko s precejšnjo gotovostjo datiramo le poslednji Sofoklovi dramski besedili: Filokteta, ki je nastal leta 409 pr. Kr. (avtor je istega leta zmagal), in Ojdipa $v$ Kolonu, iz leta 406 pr. Kr. (s to dramo je spet zmagal, tokrat v postumni produkciji svojega vnuka leta 401 pr. Kr.). Nobenega dvoma ni, da je Sofokles večkrat slavil tudi pozneje,

${ }^{1}$ Verzi $80-82$. Vsi prevodi, ki nimajo polnih referenc, so avtorjevi.

${ }^{2}$ Miloš N. Đurić v Zgodovini helenske književnosti pravi, da je šlo za 130 dram (288). Albin Lesky piše, da je Sofokles za sabo pustil 123 del (130).

${ }^{3}$ Za drugačno filološko stališče, po katerem Sofoklovo avtorstvo ni več sporno, glej Krumreich, Pechstein in Seidensticker 280. 
npr. leta 438 pr. Kr., ko je premagal Evripida, ki je takrat nastopil s trilogijo, v kateri je bila Alkestida uvrščena med satirske drame. Leta 431 pr. Kr. je zmagal Ajshilov sin Evforion, tretje mesto pa je tedaj pripadlo Evripidu, ki je med drugim uprizoril Medejo (gl. Sommerstein, Aeschylean 13). Vemo, da je Sofokles osvajal prve nagrade tudi v letih, ko so bile na sporedu njegove (tudi dandanes) najslavnejše drame. To npr. velja za Antigono, za Kralja Ojdipa pa ne - premagal ga je namreč Ajshilov nečak Filokles (gl. Sommerstein, Aeschylean 13, predvsem op. 37 , kjer je naveden antični vir) -, vendar ni znano, kdaj točno se je vse to dogajalo in ali sta ti drami sodili $\mathrm{v}$ isti trodelni ciklus ali $\mathrm{v}$ različne cikluse. V splošnem je kronologija (in s tem biografija) v tem pogledu izredno nejasna in nezanesljiva, sodbe sodobne literarne zgodovine pa izjemno hipotetične. Poleg naštetih del so znani še naslovi sedemdesetih Sofoklovih dram, katerim pripisujejo ohranjene fragmente: nekaj več kot 2200 verzov, kar je približno enako kot drama in pol. Vprašanje pa je, ali so vsi ti odlomki dejansko Sofoklovi, saj večina poročil o avtorstvu izhaja iz enega vira, le redko iz dveh povezanih virov.

Pri naštetih dramah in omenjenih fragmentih gre za dela, za katerimi so ostale snovne sledi. Naslovov, ki jih omenjajo različni avtorji in od katerih ni ohranjen noben verz, pač pa zgolj opomba, da je »delo napisal Sofokles«, je še veliko več.

\section{Mala tekstološka razlaga Sofoklove dediščine}

Ko se je Sofokles poslovil, je bil najslavnejši človek v civiliziranem delu človeštva (tako so namreč Atenci razumeli svojo kulturo). Ta slava je trajala še celo stoletje po njegovi smrti. Po Aristotelovem mnenju (gl. Poetika 1453b2) je Kralj Ojdip paradigma maksimaliziranja tragičnega efekta. Toda slava, kot vemo, kopni in sčasoma zbledi, še posebno, če po avtorjevi smrti napoči turbulentno obdobje civilizacijskega propada. Dejstva, ki smo jih navedli glede preživetja Sofoklovih dram, so precej neizprosna. Obenem lahko zanesljivo datiramo največ tri pesnikove zmage (leta 401 pr. Kr. in 438 pr. Kr. povsem zanesljivo, leta 468 pr. Kr. zelo zanesljivo); zmaga s tetralogijo, ki je vsebovala Antigono, ni bila na nobeno od teh letnic, a ne vemo zagotovo, kdaj je bila. Kako pa je z drugimi dionizijskimi slavji, katerih nagrajenec je nedvomno bil? Kako je sploh mogoče, da ni ohranjenih več del najpopularnejšega antičnega dramatika?

$\mathrm{Na}$ ta vprašanja tu odgovarjam karseda na kratko. Dejstvo, da je bil Sofokles ljubljenec žirije, ali tistega dela javnosti, ki ji dandanes rečemo 
"akademska", medtem ko je bil Evripid miljenec ljudstva, je morda prvi možni odgovor na to, zakaj je ohranjenih trikrat več del mlajšega kot starejšega dramatika. Papirusi del nagrajencev so se nahajali v enem, častnem prostoru, pogosto $\mathrm{v}$ središču mesta, popularna dela pa so se prepisovala in raznašala po najrazličnejših atenskih krajih, in celo po drugih, oddaljenih polisih. $V$ antiki in srednjem veku so rokopisi najpogosteje izginjali zaradi požarov v knjižnjicah. Zato je bilo Sofoklova dela - če skratka predpostavimo, da so bila številna zbrana $\mathrm{v}$ enem samem osrednjem prostoru - veliko težje ohraniti kot pa Evripidove drame, ki so bile razsejane povsod naokrog.

Manjši, a neizpodbiten vpliv na to, ali se bo neko delo ohranilo ali ne, predstavlja tudi njegova vsebina in forma izražanja. Vso antično dediščino so v srednjem veku obravnavali kot "poganske posle«; ta dediščina je bila dovolj dobra za pouk grščine in latinščine, vendar ne zaradi samih antičnih virov, temveč zaradi dejstva, da je bila v srednjem veku latinščina uradni cerkveni jezik na evropskem Zahodu ter da je bila Biblija deloma pisana v grščini (ki jo je Vzhodno rimsko cesarstvo prevzelo kot uradni jezik Cerkve). Veliko antičnih dram je bilo v zgodnjem srednjem veku uničenih, ker so bile na nekaterih mestih, kjer so se ohranile (žal tudi v zadnjih prepisanih izvodih), razglašene za heretične. Kakšne so bile - v luči tega dejstva - zadeve glede Sofokla in Evripida?

$\mathrm{Na}$ prvi pogled bi se zdelo, da je imel v srednjeveškem sistemu vrednot prednost Sofokles. Organizirani in kanonizirani grški atiški dialekt, urejene misli, spretno načrtovani poduki in skladnost Sofoklovih del bi verjetno vzbudili večjo pozornost srednjeveških sholiastov. Ali pa to vendarle ni bilo tako? Videti je, da se je zgodilo prav nasprotno. Grški viri so bili za srednjeveške preučevalce nekoliko »skrivnostni«. V njih je bilo treba najti neko prerokbo ali skrivnosten božji nauk, zapisan pri poganskih narodih, ki Gospoda niti še niso poznali. $V$ takšnem sistemu razumevanja antičnega izročila je bil sofist Evripid neprekosljiva veličina.

Množica sumljivih umevanj, okretnost v rabi stilskih figur, povezovanje nepovezanih stvari, vzpostavljanje skorajda alkimističnih vezi med duhom in telesom - vse to je, paradoksno, Salamincu Evripidu omogočilo, da je nemirno poltisočletje zgodnjega srednjega veka preživel bolj na varnem, vse do enajstega stoletja, ko je bilo v magistralnih prepisih kanonizirano tisto, kar je bilo dotlej ohranjeno.

Morda se je ravno zato zgodilo, da je štiri stoletja pozneje - $\mathrm{v}$ času iznajdbe Gutembergovega knjigotiska, ki je za vekomaj zbral vse, kar ljudje in požari od antike naprej niso zmogli uničiti in sežgati - Evripid ostal skoraj trikrat bolj zastopan avtor kot Sofokles. 
Toda umetnosti ne merimo na kilogram. Sofokla so v obdobju renesanse in razsvetljenstva takoj prepoznali kot klasika. Kralj Ojdip je prva Sofoklova drama, ki je bila postavljena na novoveški oder - v gledališču Olimpico v Vicenzi, konec 16. stoletja. ${ }^{4}$ Tudi druga dela, predvsem Antigona, so bila uprizarjana v sami zarji gledališkega življenja v Franciji, Britaniji in nemških grofijah. Lik Ojdipa je Freud uporabil pri opredelitvi slovitega ojdipovskega kompleksa. Sofoklova Elektra je pozneje posodila ime nasprotnemu medspolnemu razmerju, t. i. Elektrinem kompleksu. Elektra je postala inspiracija za Eugenea O'Neilla (Elektra $v$ ćrnini) in Richarda Straussa (Elektra), operni oratorij Oedipus Rex Igorja Stravinskega pa je še dandanes pogosto na repertoarjih.

\section{Gledališče v Sofoklovem obdobju}

V zreli dobi Sofoklovega ustvarjanja je antični teater precej napredoval in se popolnoma osamosvojil od zborske pesmi, iz katere je izhajal. To pomeni redukcijo vloge zbora, njegovo razdelitev na polzbore z zborovodjo in uvajanje tretjega lika v dramo. Prav Sofoklu pripisujejo, da je uvedel tretjega igralca in povečal število pevcev z začetnih 12 na 15, tako da se lahko razdelijo $\mathrm{v}$ dve skupini s sedmimi pevci, z zborovodjo na čelu.

Celo na področju odrske tehnike se takrat, po letu 450 pr. Kr., dogajajo velike spremembe, čeprav so dionizije in na njih uprizarjane drame še vedno umetniško, pa tudi religiozno dejanje, ob katerem mora občinstvo doživeti vznemirjenje in predvsem razsvetljenje. Vendar pa je umetniški značaj odrskih prireditev v Sofoklovem času postal vse bolj pomemben. V Atenah se je vse odvijalo v enem gledališču, Dionizovem. Kapacitete - ki jih večina novejših raziskav ocenuje na približno 17.000 gledalcev - so se povečevale, gradili so se novi avditoriji in vse to je zahtevalo izboljšanje scenskih rekvizitov.

V obdobju po letu 450 pr. Kr. je izboljšano tudi ustje na tragiških maskah, ki so jih morali nositi vsi igralci. Ta ustja imajo - kot so pokazale novejše arheološke raziskave - lijakasto oblikovano odprtino, ki naj bi igralcem služila kot svojevrstni ojačevalec glasu, saj so bili avditoriji vse večji in je moral igralec glasovno doseči tudi zadnje vrste. $V$ času, o katerem govorimo, je patentirana še odprtina na steni, ki je pregrajevala oder. Odprtina (znana kot ekkyklema) je imela le en sam smoter: ob pravem času razkriti telo umorjenega tragiškega mučenca.

${ }^{4}$ Kralja Ojdipa se tradicionalno navaja tudi kot prvo (dokumentirano) moderno uprizoritev grške tragedije, a je, kot kažejo novejše raziskave, to v resnici bila Evripidova Hekaba, leta 1506 v Rimu; gl. Helou 3-4, Turkeltauh 137. 
Tudi sama produkcija je postajala odrsko vse bolj zahtevna. $S$ tremi igralci - vsak izmed njih je seveda igral več vlog - so zdaj na odru lahko prirejali resnejšo mizansceno. Kar je bilo še nekaj desetletij nazaj pri Ajshilu navadna pregraja $\mathrm{z}$ naslikanim predelom ali kakšno zgradbo ali palačo, je postalo pristni scenski rekvizit, s sklesanimi stebri, okni in frizi. V Sofoklovem času igralec ni bil samo na eni ravni (odrskem parterju), temveč pogosto na dveh ali več. Tipična scena je približno takšna: boginja na piedestalu, tragiški junak na vrhu majhnega podija, h kateremu vodijo tri stopnice, sel pa ob vznožju stopnišča oz. na odrskem parterju. Razvijejo se tudi drugi scenski rekviziti, npr. prva dvigala, najbrž največja antična gledališka iznajdba 5. stoletja pr. Kr. Kdo bi lahko pripomnil, da je vse to zgolj scenska tehnika, ki sploh ne poraja umetniške lepote. Vendar se moramo spomniti grških nazorov o gledališču kot prostoru umetnosti, ki išče predvsem neko znanje (téchne). Tega močnega razvoja odrske tehnike seveda niso mogla spregledati niti dramska besedila. Anagnoreza, dramski obrati, dialogi treh likov hkrati (namesto duetov je šlo takrat za tercete, če si lahko izposodimo današnji operni besednjak) - vse to je privedlo do novega dramskega tempa, pospešilo kontrastnost karakterologije in iz drame naredilo bolj igralsko kot ritualno dejanje.

\section{Sofoklov jezik in verz}

Grščina, v kateri so napisane Sofoklove tragedije, se v osnovi ne razlikuje od dominantne, lahko bi rekli "paradne« odrske helenske govorice, ki je prisotna pri vseh treh tragedih. Pa vendar, če nekoliko pozorneje pogledamo pesnikove monologe in replike, takoj opazimo - tudi na ravni jezika - zakaj je Sofokles tako močno zaslovel med sodobniki in poznejšimi rodovi recipientov.

Najprej gre za skladnost določenih dramskih delov. Sofoklovi monologi so, za razloček od Evripidovih, precej kratki. Pri njem ni moč opaziti toliko zemljevidnih ali zgodovinopisnih deskripcij kot pri Ajshilu. Kadar - podobno drugim dramatikom - znova pripoveduje o zločinu, ki ga na atenskem odru zaradi nespodobnosti nikakor niso smeli prikazovati, ne posega po dolgih glasniških monologih. Zato dogajanje $\mathrm{v}$ njegovih dramah teče bolj neovirano, liki pa se drug z drugim bolj gibko izmenjujejo. Celo takrat, ko gre za očitne primesi sofizmov, drobnjakarskih umevanj, je to pri Sofoklu gibkeje vključeno $\mathrm{v}$ dramo in je podobno organski, ne mehanični prilogi, kot se to pogosto zgodi pri Evripidu. 
To je tisto, kar opazimo na prvi pogled. Če potem svoj pogled dodatno izostrimo in ga usmerimo na same verze, zlahka vidimo, da so Sofoklovi jambski trimetri, ki prevladujejo v govornih dramskih segmentih, veliko skladnejši kot denimo Evripidovi. Pri Sofoklu lahko zasledimo manj verznih prestopov. Dolžina njegovih stavkov je najpogosteje idealna - od dveh do treh celih verzov. Sofokles redko končuje misel na polovici stiha, redko poantira prejšnji premislek s padcem $\mathrm{v}$ naslednji verz, kar se zelo pogosto dogaja pri raztrganem in romantično zanesenem najmlajšem tragediografu. Občinstvo zato dobi vtis, da je sleherni Sofoklov tekst po metrični lepoti - testamentaren.

To v veliki meri razjasnjuje, zakaj je bil pesnik tako popularen. Antični avditorij, kot vemo, ni cenil niti ni v polnem smislu poznal izvirnosti, ki je od romantike do danes povzdignjena v vrhunski atribut umetnosti. Ker je helenska tragedija zgolj znova pripovedovala mite, ki so bili znani vsakemu izobraženemu Grku, so ljudje gledališče obiskovali predvsem zato, da bi videli, kako je oblikovana določena dramatizacija, ne zato, da bi spoznali nekaj novega o odlomku mita, ki je izpostavljen na sceni. Dionizično občinstvo zato nikoli ni bilo naklonjeno Evripidovemu prenarejanju mitov, saj je venomer bolj cenilo téchne kot izvirnost pristopa.

$\mathrm{V}$ takšnem sistemu vrednot je Sofokles prav neprekosljiv. Ne meri, tako kot Evripid, na vizionarstvo, na domišljijo scenskih podob. Tudi v izbiri slogovnih sredstev je Sofokles najbližji Shakespearu. Njegova izraznost se izčrpa $\mathrm{v}$ retoričnem shematizmu, kot da bi šlo za kakšno abstraktno in ne trodimenzionalno upodobitev. Primerov takšne izraznosti je v Sofoklovih besedilih na pretek. Naslednji verzi bi lahko bili vzorec njegovega verbaliziranega kozmosa v malem:

\section{OJDIP}

Saj vaša bol velja le enemu, vsak misli nase zgolj, a duša moja ječi za mesto, zame in za vas. ${ }^{5}$ (Sofokles, Kralj 9)

Podoben primer istega izraznega sredstva najdemo v Antigoninem monologu:

\footnotetext{
${ }^{5}$ Verzi 61-64.
} 


\section{ANTIGONA}

Na vse, kar vam najdražje je, vas prosim in rotim:

$\mathrm{Na}$ vaše otroke, ženo, imetje, na boga. ${ }^{6}$ (Sofokles, Ojdip 29)

Vse to - tudi verzna oblika in distribucija besed znotraj metra, in izraznost, ki meri na retorično shematiko - je pri Sofoklu okronano s posebno, lahko rečemo "vladarsko" grščino. Vsi prevajalci iz grščine vedo, da je sintaksa atiškega narečja klasičnega petega stoletja pr. Kr. povsem drugačna od sintakse srbščine, slovenščine ali kakšnega drugega sodobnega jezika.

Avtor tega teksta se na tem mestu ne more spuščati v vse nadrobnosti in odtenke tega izredno "ekonomičnega" jezika, ampak ga lahko bralcu, ki grščine ne zna, približa prek nekaterih primerov. Grki so imeli zelo radi takšne izraze: "Storivši to, je njim, prišedši v Atene, s svojo avtoriteto sporočil tole«. Tudi kombinacija participskih glagolskih oblik z zaimki je Sofoklu pomagala do slave. Z grškega stališča je Sofokles mojster rabe zaimkov, ki so bili znamenje "velikega sloga". Prevajalec naleti na celo vrsto zaimkov: od osebnih, povratnih, svojilnih, odnosnih, nedoločnih, vprašalnih, do sestavljenih. Sodobni prevajalec se zato pogosto znajde $\mathrm{v}$ zadregi, ko skuša razumeti, kdo je komu kolikokrat in zakaj nekaj naredil, vendar so helenski gledalci to preprosto oboževali.

Dovolj je, da se spomnimo le enega primera. Sestavljeni zaimek toioûtos (»takšen « oz. »tisti, ki je tako pomemben«) Sofokles uporabi na točno 123 mestih, kar je približno dvajsetkrat v posamezni drami. Tipično rabo tega

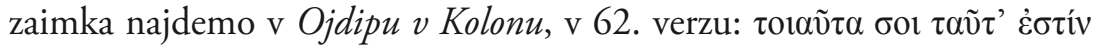
(kar pomeni: „tako je pomebno to mesto, kjer si«).

Vse doslej povedano jasno kaže na to, da Sofoklov leksični zaklad ni tako bogat kot Evripidov. Prav to je bila v očeh antičnega gledalca prednost slavnega pesnika, ker je bila za tega gledalca kodirana raba manjšega besednjaka znak pesnikove spretnosti na manjšem in bolj prepoznavnem terenu, kar je bilo vedno cenjeno kot tista famozna téchne.

\footnotetext{
${ }^{6}$ Verzi $250-251$.
} 


\section{Naslovi dram v Sofoklovem času in pozneje}

Bralcem je nedvomno že znano, da so naslovi dramskih del najverjetneje poznejši, novoveški pojav. ${ }^{7} \mathrm{~V}$ antiki so bile drame najbrž igrane tako, da jih je pisec prinesel v gledališče $\mathrm{v}$ enem pisnem izvodu, ki je najprej krožil med člani žirije. Kadar je bila trilogija sprejeta za prikaz na dionizijskih tekmovanjih, je verjetno pesnik ta isti izvod vzel nazaj in začel igralske vaje. Na samem tekmovanju so dela napovedovali z vzklicem, in tako je naslov kot umetniška kategorija precej dvomljiv.

Kar danes velja za naslov antične drame, je v glavnem kodiran naziv iz starega ali srednjega veka. Pri Evripidu tako srečemo Ifigenijo avlidsko in Ifgenijo tavridsko (ki ju danes prevajamo kot Ifigenijo v Avlidi in Ifigenijo na Tavridi). Popolnoma natančen prevod naslovov dveh Sofoklovih dram se glasi: Ojdip tiran in Ojdip med Kolončani. Marsikateri prevajalec - ta je moral najprej prevesti naslov dela - je imel veliko težav s prevodom besede "tiran", ki je v novoveški konotaciji dobila negativen pomen, medtem ko je pri Helenih pomenila preprosto »vladar". Da so bili glede tega v zadregi tudi Angleži, ki so to dramo v 20. stoletju najpogosteje prevajali, lahko vidimo iz naslednjega pregleda vseh (poslovenjenih) angleških prevodov tega dela v prejšnjem stoletju:

Kralj Ojdip (R. C. Jebb; posodobil Moses Hadas, 1967)

Oedipus Rex (Fitts, Dudley, Fitzgerald, 1939)

Kralj Ojdip (David Grene, 1942)

Kralj Ojdip (E. F. Watling, 1947)

Oedipus Rex (Albert Cook, 1948, redakcija prevoda 1957)

Kralj Ojdip (Theodore Banks, 1956)

Kralj Ojdip (Paul Roshe 1958, redakcija prevoda: 1991 in 1996)

Kralj Ojdip (Bernard Knox, 1959)

Kralj Ojdip (Piter D. Arnott, 1960)

Kralj Ojdip (Kenneth Cavander, 1962)

Kralj Edip (H. D. Kitto, 1962)

Oedipus Tyrannus (L. Berkowitz in T. Bruner, 1970)

Kralj Ojdip (Thomas Gould, 1970)

Kralj Ojdip (Robert Fagles, 1977, redakcija prevoda 1979)

Kralj Ojdip (Stephen Berg in Diskin Clay, 1978)

Kralj Ojdip (Don Taylor, 1986)

Oedipus Tyrannus (Hugh Lloyd Jones, 1994)

Oedipus Tyrannus (Peter Meineck in Paul Woodruff, 2000)

${ }^{7} \mathrm{Tu}$ je treba poudariti, da vendarle ni povsem jasno, kako je bilo zares s tem. V državnem arhivu so jih najbrž klasificirali po naslovih, tako jih poznajo tudi aleksandrinski filologi. O tem gl. Sommerstein, »The Titles« 1-16. 
Ojdip je torej vladar Teb, vendar ni kralj, še najmanj pa bi lahko bil car (kot v srbskem prevodu Miloša Djurića). Car je vladarski naslov - etimološko povezan z latinskim "cezar" -, ki pomeni vladarja istega ranga $\mathrm{z}$ rimskimi ali bizantinskimi vladarji oz. upravitelja, ki ne vlada samo nad svojim, temveč tudi nad drugimi narodi. Za carje so se razglaševali denimo ruski imperatorji ali srbski car Dušan, »vladar Srbov in Grkov«. Da je v Ojdipovem primeru raba besede car napačna, je nedvomno jasno. Ne le, da ni obvladoval drugih polisov, temveč celo na tebanskem prestolu ni bil kralj, pač pa neke vrste zaslužen upravnik.

Kaj je potem treba narediti? Poimenovati Ojdipa kralj je nekoliko skromneje, vendar srbska prevajalska tradicija po takšni rešitvi ni posegala. Sam sem ponudil svojo prevajalsko rešitev: Gospodar Ojdip, sledeč neformalnemu, a zelo znanemu naslovu prvega modernega srbskega vladarja, Miloša Obrenovića, v času omejene samostojnosti Srbije v 19. stoletju. Če natančneje razumemo besedo "tiran", lahko naslov te drame prevedemo kot Vladar Ojdip, celo Namestnik Ojdip, nikakor pa ne kot Kralj Ojdip ali Car Ojdip.

\section{O drugih naslovih in dramah}

Drugih dram, med njimi je tudi Antigona, ni tako težko nasloviti ali prevesti v sodobne jezike. Antigona, ki je tokrat v ospredju našega zanimanja, je ob Gospodarju Ojdipu najbolj paradigmatičen tekst antične dramatike v novejših časih. Antigona, zaščitnica morale in višjega reda, je vse do danes ostala primer žrtve, ki je vzidana v slavo dneva in drugih efemeralij. Ona premaga tako človeško kratkovidnost kot tudi pravne in etične norme, omejene z vsakdanjimi predsodki.

Vse, kar je Antigona povedala v drami, ki ji je dala svoje ime, znamo skoraj na pamet. To, kar pa je rekla v zadnji Sofoklovi drami Ojdip v Kolonu, je manj znano. Tu naletimo na nekaj, kar bi lahko poimenovali "Antigonin proto-lik«. Ključni moment za zgodbo o prekletstvu, ki pade na Ojdipove naslednike, najdemo v odlomku, v katerem uzurpator tebanskega prestola, general Polinejk - pred svojo silno vojsko iz Argosa - stopi pred Ojdipa in ga roti, naj preide na njegovo stran, kajti »tisti, ki ima na svoji strani slepega Ojdipa, bo zmagal« (glej verze 1458-1478).

Antigona, ki se kronološko, skladno z razvojem mita - čeprav seveda ne skladno s časom nastanka drame, saj je Ojdip v Kolonu zadnja Sofoklova drama - prvič pokaže kot sodnica "stoletja in stoletij«, ki 
očeta prosi, naj sprejme in posluša uzurpatorja Polinejka, opredeli svoj dramski značaj s temi besedami:

\author{
ANTIGONA: \\ Čuj, oče, moj nasvet, čeprav sem mlada! \\ Dovoli kralju, da ti svétuje, \\ kot mu srce veli, kot bogu všeč je, \\ in daj, da sestri srečata se z bratom! \\ Ne boj se, da bi s tem, kar ni v tvoj prid, \\ na silo odvrnil te od tvojih sklepov. \\ Le kaj ti škóduje, če govor slišišs? \\ $\mathrm{V}$ besedah se izdajo zli naklepi! \\ Tvoj sin je: in četudi bi naklepal \\ vseh hudobij najhujše ti brezboštvo, \\ ni prav da zlo mu z zlom povrneš, oče! \\ Daj, sprejmi ga! Glej, tudi drugi imajo \\ otroke slabe, ujezljiv značaj, \\ pa urok prijateljev jih umiri. \\ Ne v zdaj, poglej nazaj, kaj tvoj ti oče, \\ kaj rodna mati zla je prizadela! \\ Če v to uzreš se, vem, da boš spoznal, \\ da iz hude jeze rodi se le húdo. \\ Snovi ne malo ti je za razmislek, \\ ko trajno ugaslih si oči oropan. \\ Popusti! Kdor prosi kaj pravičnega, \\ naj ne prosjači zanj! Če kdo je užil \\ kaj dobrega, naj to še sam skazuje! (Sofokles, Ojdip 129-131)
}

Ojdip, Polinejkov oče, vendarle zavrne sina z grobimi besedami in kletvijo, Polinejk pa dojame, da nima druge izbire, kot da skrije to znamenje pred svojimi vojaki in odide gotovemu propadu naproti, $\mathrm{k}$ »vgraditvi svojega imena v tebansko slavo«. Polinejk krene v odločilni, že vnaprej izgubljeni boj, z besedami iz Ojdipa $v$ Kolonu:

\title{
POLINEJK:
}

Gorje! Zastonj bila je moja pot!

Gorje, zavezniki! S kakšnim načrtom

sem šel iz Argosa, tega, nesrečnež,

zaveznikom zaupati ne smem,

a tudi odsloviti jih ne morem.

${ }^{8}$ Verzi $1181-1204$. 
Molčati moram, vdati se v usodo!

$\mathrm{O}$, rodni sestri, ki sta slišali

neizprosno kletev našega očeta,

pri nebu vaju prosim: če se kletev

uresniči in če kdaj se vrneta

domov, vsaj vedve me ne zavrzíta,

s častjo pogrebno v grob me položita!' (Sofokles Ojdip 147-149)

S temi Polinejkovimi besedami je vse postavljeno in "zaklenjeno«. Usoda je nastavila zanko tako Polinejku kot Antigoni. Scena, prostor, grob, mesto, (ne)dostojen pogreb brata Polinejka - vse to je v nekaj mojstrskih verzih »ljudskega pesnika" Sofokla že opisano in pripravljeno za tisto slavno epizodo tebanske sage, ki je znana kot tragedija Antigona.

\section{Sofoklovo edinstveno razumevanje gledališča}

Teater, ki ga je v zlati dobi razvil Sofokles, dandanes velja za helensko tragedijo v ožjem pomenu besede. Če je etično-estetsko gibalo te dramske zvrsti hýbris, se pravi krivda, zaradi katere človek trpi, potem je Sofokles - še posebej v drami Kralj Ojdip - tragično krivdo, ki se izvršuje slepo in nevede, pripeljal praktično do popolnosti. Toda Sofokles svojemu junaku - bodisi da, kot Ojdip, naredi prestop z nejevoljo oz. nezavedno, ali pa, kot Antigona, svobodno prevzema lastno krivdo ne pusti niti najmanj prostora za premislek, predramek ali strah. Za Evripidove značaje pa velja nekaj povsem drugega. Ti so čezmerni, drzni, pogosto v sebi razcepljeni. Vsak Evripidov junak lahko iz drame izstopi in pregrehe ne stori, ne glede na to, da je izhod pogosto lažen ali nedojemljiv. Pri Sofoklu takšnih izhodnih vrat preprosto ni. Na ravni volje - če voljo razumemo kot manifestnost gest, ki lahko dejansko spremenijo junakov svet - Sofoklov tragiški protagonist ne more storiti ničesar. Moralni zakoni v človeku so nezlomljivi, nebo nad njimi neizprosno. Tudi kadar so rokohitrski, kakor Ojdip, ali polni zanosa, kakor Antigona, kadar so dosledni, kakor Kreon, nikakor ne morejo v realnem času izstopiti iz dramske pasti.

Tako pri današnjem kot pri antičnem gledalcu to porodi katarzo, saj je znano, da se velika umetnost od majhne razlikuje po tem, da se v veliki umetnosti vse nujno zgodi tako, kot se, medtem ko se v primeru majhne ali nizke umetnosti, ki je oropana talenta, venomer vprašu-

\footnotetext{
${ }^{9}$ Verzi $1399-1410$.
} 
jemo, ali je vse v resnici moralo biti tako, zakaj se je tako začelo, in nenazadnje, zakaj se je prav na tem mestu in na ta način končalo.

Prav zato je Sofokles veliki umetnik. V njegovih tragedijah se vse giblje kot deli tanka: gosenice hýbris poganjajo jeklena kolesa volje junaka, ki preučuje svoj primer tako, da s prstom kaže nase, pri čemer se na koncu vedno kot edina možnost pokaže to, da bogovi zagrmijo iz topa in se junakova drama konča kot tragedija. Temu sosledju se nihče ne more umakniti, še najmanj Antigona. Le en popotnik je deloma dobil priložnost za odrešenje: sam Ojdip. To pa je tema, o kateri bomo govorili v nekem drugem tekstu.

\section{Prevedel Milosav Gudović}

\section{LITERATURA}

Aristofan. Praznovalke tezmoforij. Žabe. Prev. Andreja Inkret. Ljubljana: Mladinska knjiga, 2003.

Aristotel. O pesniški umetnosti. Prev. Kajetan Gantar. Ljubljana: Študentska založba, 2005.

Đurić, Miloš. Istorija helenske književnosti. Beograd: Zavod za udžbenike i nastavna sredsta, 1986.

Helou, Ariana N. Translation and Performance of Greek Tragedy in the Cinquecento. Providence, RI: Brown University, 2007.

Krumreich, Ralf, Pechstein, Nikolaus in Bernd Seidensticker. Das grichische Satyrspiel. Darmstadt: Wissenschaftliche Buuchgesellschaft, 1999.

Lesky, Albin. Die griechische Tragödie. Stuttgart: Kröner, 1981.

Prinsky, Norman. Ancient Times through the Renaissance: Notes and Questions on Drama and Sophocles' Oedipus the King. Augusta, GA: Augusta State University, 2001.

Sofokles. Antigona. Prev. Kajetan Gantar. Ljubljana: Mladinska knjiga, 1978.

Sofokles. Kralj Oidipus. Prev. Anton Sovrè. Ljubljana: Mladinska knjiga, 1978.

Sofokles. Ojdip v Kolonu. Prev. Kajetan Gantar. Celje: Celjska Mohorjeva družba, 2010.

Sommerstein, Alan H. Aeschylean Tragedy. London: Duckworth, 2010.

Sommerstein, Alan H. "The Titles of Greek Dramas«. Seminari Romani di Cultura Greca 5.1 (2002): 1-16.

Turkeltauh, Daniel. "Hecuba«. A Companion to Euripides. Ur. Laura K. McClure. Malden, Oxford: Willey Blackwell. 136-151. 


\section{Sophocles: Life and Work Collected in Only Seven Plays}

Keywords: Greek tragedy / Greek drama / Sophocles / Antigone / Oedipus at Colonus

Sophocles was the ancient Shakespeare. Not only is he a link between the ancient and the new Greek theater, but with the clarity of his style, the precise verse, and the perfectly refined tragedy, he was for centuries the model of a writer for the ancient Greeks and their heirs. Yet almost three times less tragedies has survived from Sophocles than from Euripides. Why is this so? Textual analysis indicates that this is precisely because Sophocles was canonized and his plays in manuscripts were preserved in a small number of special places. Today, seven plays survive and one that is still uncertainly attributed to Sophocles. Antigone is among the tragedies that have formed the backbone of understanding Sophocles for centuries. Less well known is that a kind of proto-Antigone exists in Sophocles's last written play: Oedipus at Colonus.

1.01 Izvirni znanstveni članek / Original scientific article

UDK 821.14'02.09Sophocles

DOI: https://doi.org/10.3986/pkn.v44.11.01 